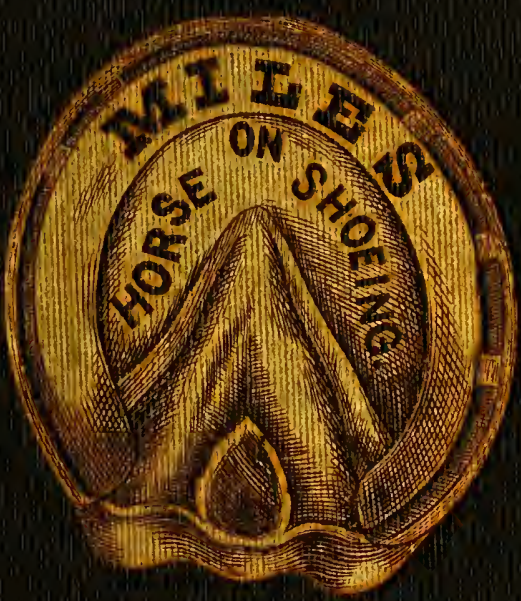




\section{LIBRARY UNNIVERSITY Y PENNSYLVANIA}

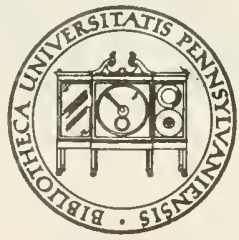

Rittrohouser Orrmy VRG19.19 FAIRMÁN ROGERS COLLECTION $\mathrm{ON}$ HORSEMANSHIP 1856 
University of Pennsylvania School of Veterinary Medicine C. J. Mam " T,ibrary Plf - 

Digitized by the Internet Archive in 2009 with funding from

Lyrasis Members and Sloan Foundation 



\title{
PLAIN TREATISE
}

oy

\section{HORSE-SHOEING.}

WITH ILLUSTRATIONS.

\section{WILLIAM MILES, EsQ., AUTHOR OF "THE HORSE'S FOOT, ETC."}

\author{
PII I L ADE LPH I A : \\ HENRY CAREY BAIRD, \\ (SUCCESSOR TO E. L. CARET,
}

No. 7 HART'S BUILDINGS, SIXTH ST. ABOFE CHESTNUT.

1856 . 
$(1 / f$ NEW BOLTON

019.96
Nia 96
1956

STEREOTYPED IF L. JOHNSON \& CO.

PHILADELPHIA.

PRINTED BY T. K. AND P. G. COLLINS. 


\section{O NTE NTS.}

PAGE

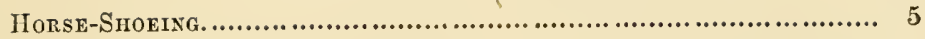

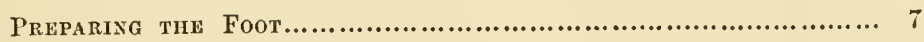

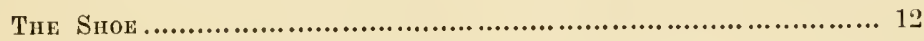

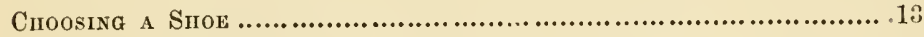

Cutting off the Heels.............................................. 14

The NaIL-Holes..................................................... 16

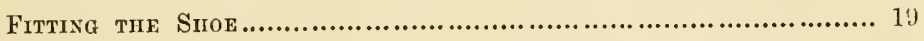

Filing UP THE SHOE................................................

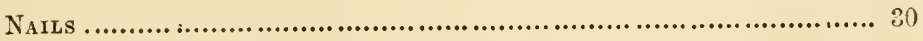

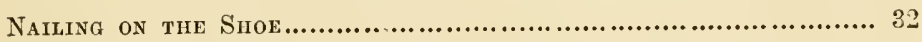

ShoEING With Leather........................................... 84

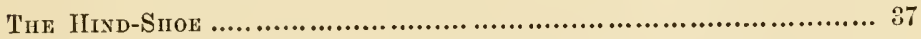

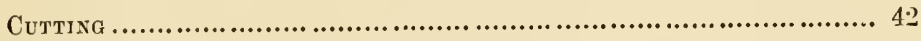

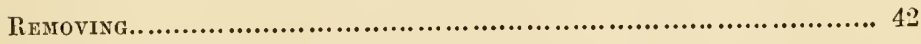

General Observations............................................... 44 
$\checkmark$

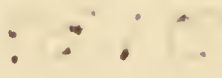




\section{HORSE-SHOEING.}

Iт has been suggested to me, by several correspondents, that a plain, practical treatise on HorseShoeing, divested of all other matters, connected with the soundness of the horse's foot, would be very acceptable to many working smiths, who have neither the time nor the inclination to wade through a work where what they want to find is mixed up with other matters, which do not bear upon their vocation. To the production of such a treatise I now set myself, in the hope that, however much I may fall short of my wishes, I may still in some degree supply a want which has long been felt by many. The books at present in use are written in a style that most smiths find it difficult to follow; my aim, therefore, shall be to convey the information I have to offer in the simplest lan-

$$
1 *
$$$$
5
$$ 
guage I can command, and such as the leastinformed among them are familiar with. But, before I enter upon the subject of shoeing, I must notice two things, which we must not only believe, but act upon, if we ever hope to arrive at really good shoeing: the first is, that nature has given to what horsemen call a good-shaped foot the form best suited to the horse's wants; and the second is, that the hoof expands when the horse's weight is thrown upon it, and contracts when it is taken off again. But the mere belief in these things will be of no use, unless we make the shoe to fit the foot, and nail it on in such a manner as will allow the hoof to expand and contract; for we might as well not believe at all, as believe a thing to be right, and not do it.

Nailing an iron shoe to a living horse's foot is a very unnatural thing to do; but, as it must be done, it is our duty to see how we can do it with the least injury to the horse. To show this, I will suppose myself addressing a young smith, who is about to shoe his first loorse. 


\section{PREPARING THE FOOT.}

You must begin by taking off one of the old shoes, and I say one, because the other should always be left on, for the horse to stand upon: he is sure to stand quieter upon a shod foot than he can upon a bare one; and it will prevent his breaking the crust. Raise every one of the clenches with the buffer, and, if the shoe will not then come off easily, loosen some of the nails with the punch; but never tear the shoe off by main force: it splits the crust, and widens the nail-holes. The shoe being off, you should rasp the edge of the hoof all round, and take out any stubs that may be left in the crust. Then you must pare out the foot; and this requires both care and thought. If the horse has a strong, upright foot, with plenty of horn, you should shorten the toe, lower the heels and crust, and cut out the dead horn from the sole, and also from the corners between the. heels and the bars; the best way of doing this is to pare the bars down nearly even with the 
sole, and then you can get at the dead horn in the corners more easily. The part of the bar which stands up above the sole would have been worn away, or broken down, if the shoe had not kept the hoof off the ground; therefore you had better always pare it down, but on no account ever cut any thing away from the sides of the bars, or what is called "open out the heels;" and be sure that you never touch the frog - with a knife. Now remember that there are three things which you must never do in paring out a foot: you must never cut the sides of the bars, or open out the heels, or pare the frog; and I will tell you why you must never do them.

The bars are placed where they are, to keep the heels from closing in upon the frog; and if you trim them by cutting their sides, you weaken them, and they can no longer do it, and the foot begins to contract.

Opening out the heels does exactly the same thing, by weakening the very parts which nature placed there to keep the heels apart. Now it 
takes some time to contract a horse's foot so as to lame him, and, because the contraction comes on by slow degrees, no one notices it, until the horse falls lame, and then every one wonders what can have done it; but very few hit upon the right cause.

The frog is a thick, springy cushion, whose chief use is to protect a very important joint, called the navicular joint, and it is covered by a thin layer of horn, to keep in the moisture; and every time you slice off any of the frog, you lay bare a part that was never meant to be exposed to the air, and it dries, and cracks, and forms rags, which are cut off at every fresh shoeing, until the whole frog becomes as dry and hard as a board; and the horse gets an incurable disease, called "navicular disease;" therefore I say, leave the frog alone; it will never grow too large, for, long before that would happen, the outer covering will shell off, and a new horny covering will be found underneath; and as to the rags, leave them alone also, and they will fall off of themselves. 
A weak, flat foot will bare very little paring or rasping; the crust of such a foot is sure to be thin at the toe, low at the heels, and the sole thin and weak; therefore, the less you do to it the better, beyond getting rid of the little dead horn there may be, and making the crust level where it is to bear upon the shoe; this must be done to all feet, and, as the inner quarter, where there should be no nails, does not wear away as fast as the outer quarter, where the nails are driven, you should always place a rasp upon its edge across the foot, to be quite sure that the two sides are level. I have known shoes lost from the inside quarter being higher than the outside, and causing the foot to bear unevenly on the shoe.

Before you pare out a foot, you should always think of the state of the roads; and if they are dry, and covered with loose stones, or have been lately repaired, you should take very little off the sole of any foot, because, if you thin it, the stones will bruise it; but when the season is wet, and the stones worn in, you may pare out the sole of 


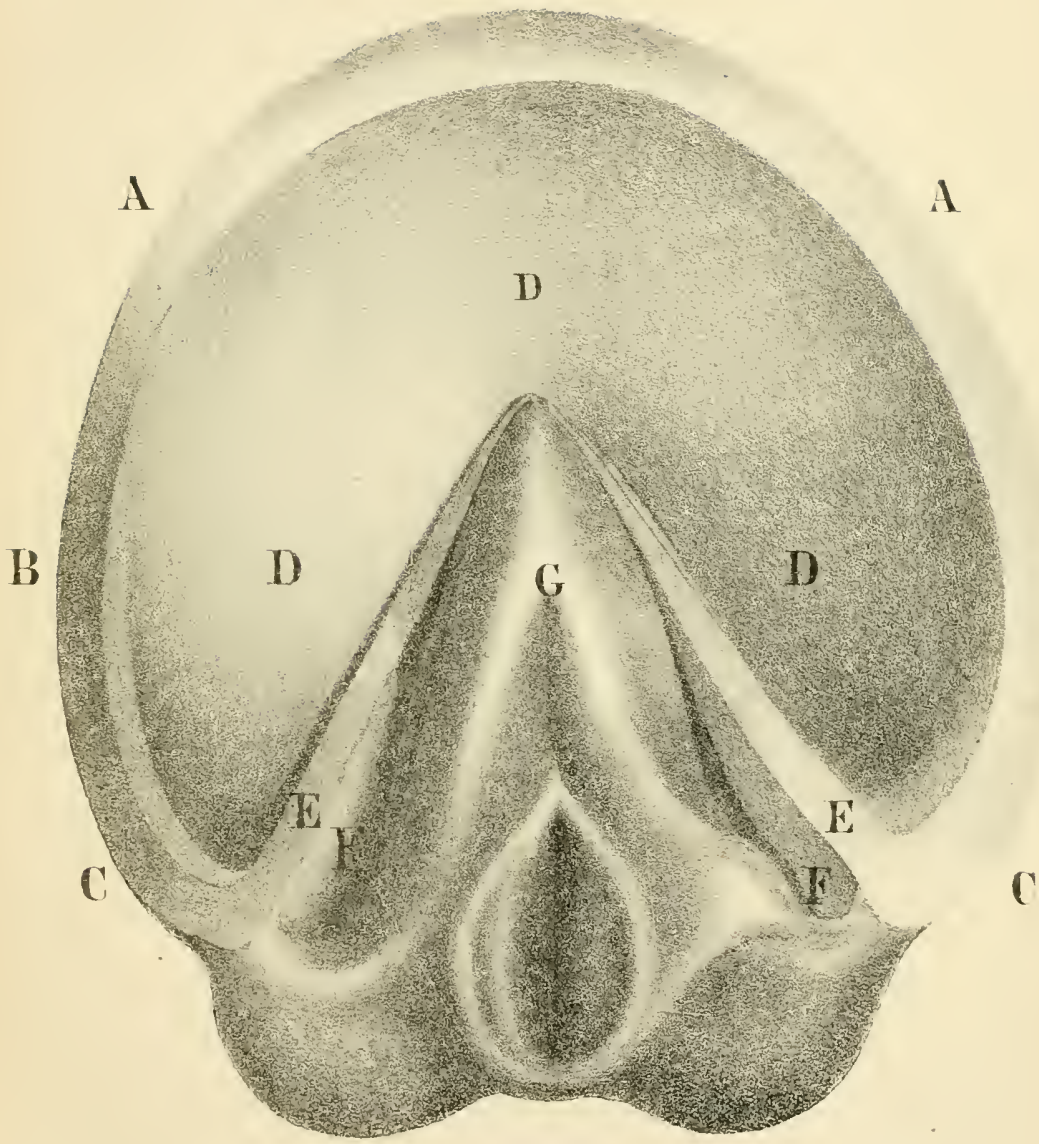



a strong foot until it will yield to hard pressure from your thumbs; but you nust never pare it thin enough to yield to light pressure.

Plate I. shows a good-shaped near forefoot, pared out ready for shoeing. I have placed letters against the different parts. The toc reaches from $A$ to $A$, the letter $B$ shows the middle of each quarter, and $\mathrm{C}$ marks the heels. You will observe that the crust is thicker on the outer quarter, where the nails should be, than it is on the inner quarter, where a nail must never be driven; and you will also see that the hoof is not a circle, as some suppose, but is straighter on the inside than it is on the outside. D marks the sole; E shows the upper part of the bars, pared down nearly level with the sole. $\mathrm{F}$ shows that part of the bars which must never be touched by a knife; $G$ marks the frog, and is placed just over the situation of the navicular joint. I would advise you to examine this frog well, because it is what every horse's frog should look like,-plump, and full, and even, with a broad, shallow cleft, 
not split through at the back part; and, if you shoe your horses properly, and never pare the frog, it is what their frogs will come to in time.

\section{THE SHOE.}

Before I talk about the shoe, I must settle names for the upper and under surfaces; because I fear I should mislead those who are not smiths, if I call the part that rests upon the ground "the upper surface," as smiths do; I shall therefore call that part of the shoe "the ground surface;" and the part which goes next the foot I shall call "the foot surface;" and then there can be no mistake as to which surface I mean.

In turning your store shoes "in the rough," you should leave them longer at the heels than smiths generally do: we shall see the reason for it when we come to "fitting the shoe;" and you should make the web as wide at the heels as it is at the toe, and of the same thickness throughout from the toe back to the heels. The 
"fuller" should be carried quite round the shoe to the heels, and the fullering-iron should have both sides alike. It is a far better tool than the one-sided iron in common use, which is generally so narrow and sharp that it not only makes the groove too small for the heads of the nails to sink into, but it often splits the shoe. A narrow groove may look neater than a wide one; but you will find a wide one much more useful.

\section{CHOOSING A SHOE.}

The first thing to look to in choosing a shoe is the kind of foot you liave to deal with. If the foot is a strong, good-shaped one, it will be an easy matter to find a shoe for it; only take care that the web is not too narrow, and that the shoe is not too light. A light shoe is apt to bend before it is half worn out; and the pain caused by the pressure of the bent nails against the tender lining of the hoof throws the horse down, and most likely breaks his knees. If the 
foot should be flat, with a weak, brittle crust, you must still choose a stout shoe; for a horse with such a foot could not go at all upon a bent shoe; and the shoe must have a wide web, because the sole is sure to be thin and will need plenty of cover to protect it.

You must also look to the seating; for, if the foot is weak and flat, the shoe must be well seated out, to prevent its pressing upon and bruising the sole; but if the foot is strong, and the sole arched, there need not be more seating than will allow the point of a picker to pass freely round between the sole and the shoe; otherwise dirt and small stones will get in, and bruise the sole as much as the shoe would do if it pressed upon it.

\section{CUTTING OFF THE HEELS.}

Having fixed upon a shoe to your mind, begin by cutting off the heels: and you will find a halfround chisel a better tool for the purpose than a straight one, becanse you should never cut them 

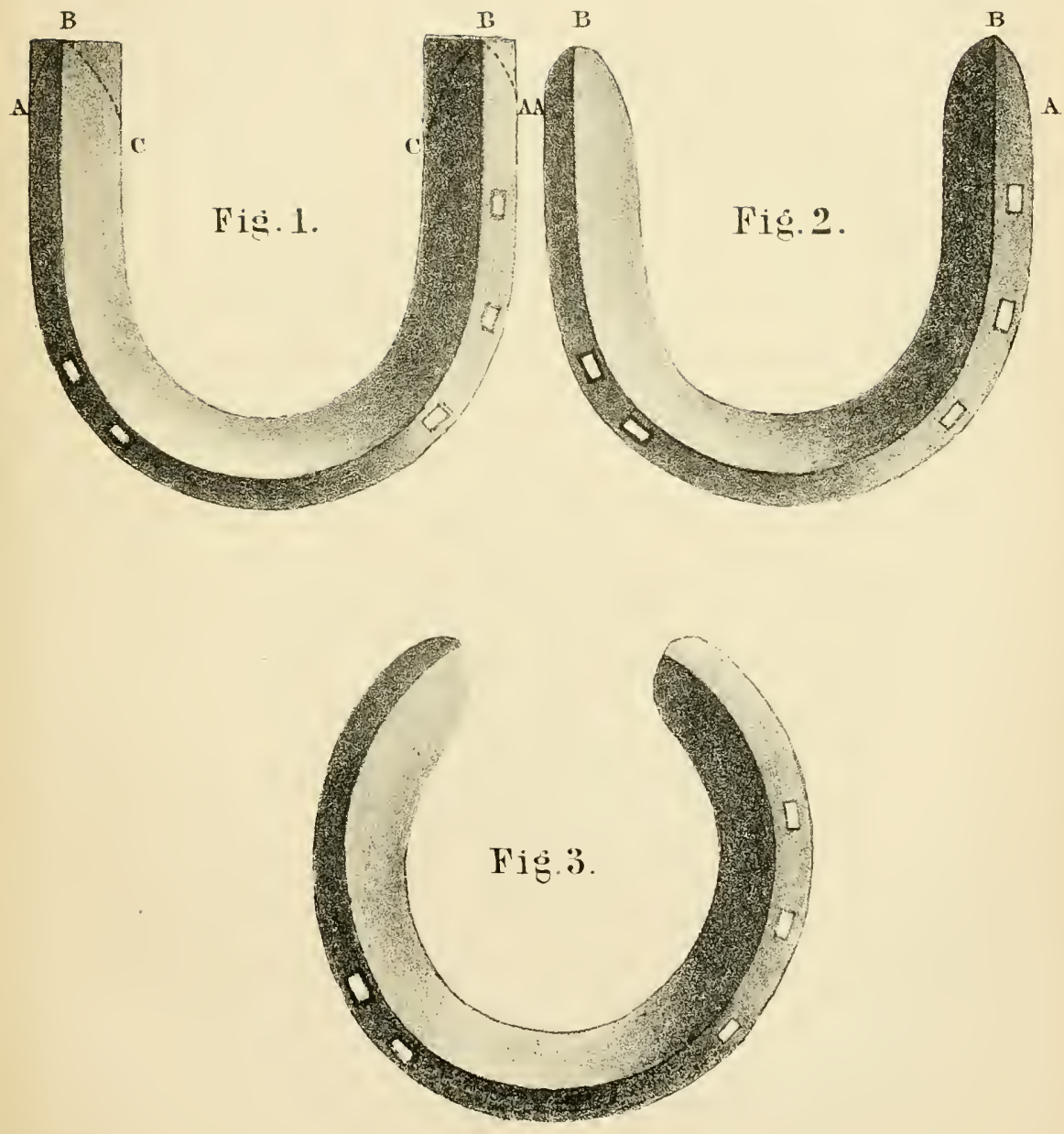

HERLINE \& CO LITH. PHIL: 

off square; if you do, you will find it impossible to fit the shoe properly to the heels, and at the same time keep the web as wide at the heels as it is at the toe; for one of the corners of the shoe will be sticking into the frog, while the other stands out beyond the crust; but if you cut them off as shown in Plate II., Fig. 1, you will have no difficulty in bringing every part of the shoe into its proper place upon the foot. Fig. 1 is a shoe turned in the rough; and the dotted lines show the direction in which the heels should be cut off. The side next the frog should be cut off from $C$ to $B$, and the outer corner from $A$ to $B$, and then the shoe will look like Fig. 2, which with a little hammering over the beak of the anvil will soon come like Fig. 3: you will see that the points, marked $\mathrm{A}$ in Fig. 2, have disappeared in Fig. 3, and that the parts between $A$ and $B$ on each side have become a portion of the outer rim of the shoe; whereby the outer rim is lengthened, and the inner rim shortened; and there are no corners left to interfere with your following 
the sweep of the heels, and you are enabled to keep the web as wide at the heels as it is at the toe. I have introduced Fig. 3 in this place, beeause it gave me the opportmity of explaining the reason for eutting off the heels as I have directed; but at this stage of the business it is a good plan always to leave the quarters and heels rather straight, and wide apart, until you have fitted the toe; because it is less trouble to bring them in than it is to open them out after the front has been fitted.

\section{THE NAIL-HOLES.}

You must next open the nail-holes; but be sure that they have been stamped so as to pass straight through the shoe, and eome out in the flat part of the web and not partly in the flat and partly in the seating. It is a very bad plan to make them slant inwards, as most smiths do; for in driving a nail they have first to pitch the point inwards, then turn it outwards, driving it 
all the time with the grain of the crust, and at last they bring it out high up in the thinnest part of the hoof, and have the weakest part of the nail for a clench. Now, instead of all this, if you make the holes straight through the shoe, you have only to drive the nail straight, and it will go through the shoe across the grain of the crust and come out low down in the thickest part of the hoof, and give you a strong clench made out of the shink of the nail instead of a weak one made out of the point. The advantage of straight holing is that you are sure never to prick the foot in driving a nail, and you get a firmer hold for the shoe. Everybody knows that a short purchase across the line of the strain is stronger than a longer one in the direction of the strain.

The soundness of the horse's foot, as far as shoeing is concerned, depends more upon the number of nails and where they are placed than upon any thing else; for if the shoe is ever so badly formed, and the nail-holes are rightly placed, very little harm will happen to the foot beyond 
the loss of a shoe; but if the shoe is of the best possible shape and fitted to the foot in the most perfect manner, unless the nail-holes are placed so that the foot can expand, it must in the end become unsound.

The portion of hoof that expands the most is the inner quarter and heel. You must therefore leave those parts free from nails; and the way to do it is never to stamp more than two holes on the inside of the shoe, one about an inch and a quarter from the centre of the toe, and the other about three-quarters of an inch behind it. It is quite clear that, if you mail both sides of a horse's hoof to an iron shoe, the hoof will be held fast, and cannot expand; and, when the horse's weight forces the bones of the foot down into the hoof, the tender lining of the hoof will be squeezed against the shanks of the nails and cause pain to the horse at every step he takes. The whole number of nail-holes should never exceed five; three on the outside, and trro on the inside. I have proved over and over again that five nails 
will hold on a fore-shoe at any kind of work, in any country and at any pace. If a shoe is properly fitted to the foot and fastened by five nails, nothing but the smitll's pincers can get it off.

Having cut off the heels and opened the nailholes, you must next turn up a clip at the toe. Every shoe should have one at the toe; it keeps the shoe steady, and prevents its being forced back. But you never should put one at the side; for if it is put on the inside it prevents the hoof expanding; and on the outside it is worse than useless, for the nails there are quite sufficient to keep the shoe from working across the foot, and the clip will interfere with the placing of one of the nails and destroy more of the crust than two nails would do.

\section{FITTING THE SHOE.}

You must never forget that "fitting the shoe" means making the shoe fit the foot, and not making the foot fit the shoe, as I have often seen done. 
It is a bad plan to try to fit the whole of the shoe at once; it is much better and saves a great deal of trouble to fit the toe first, then the quarters, and lastly the heels: but, before you begin to fit the toe, take a look at the old shoe, and see how much of the toe of it is worn away, because just so much of the new shoe should be turned up away from the ground out of the line of wear.

We all know that horses go better and stumble less in old shoes than they do in new ones; and the reason why they do so is because they have worn away the toe, and no longer jar the foot by striking the toe against hard substances in the road. A new shoe turned up at the toe is the same thing to the horse as an old one worn down, but with this great difference to his comfort:that he is easy upon the new one from the time it is first put on, whereas he was never easy upon the old one until he had worn the toe away.

When a horse wears his shoe hard at the toe, it is the custom of most smiths to weld a lump 

of steel on to it, to make him longer in wearing it away; but this only increases the jar to his foot, while turning up the toe makes the shoe last quite as long, and saves the horse from a great deal of unnecessary suffering. A strong foot will bear the toe to be turned up a good deal; but a flat foot is always weak at the toe, and will not bear much. Still, the shoe should be turned up a little, so as to clear the ground; the horse will travel safer and better for it.

You can make a very handy tool for turning up the toe of a shoe by shutting a piece of iron, five inches long and one inch broad, crosswise on to each blade of a pair of smith's tongs; with this tool you will be able to grasp both limbs of the shoe at once, and not only turn up the toe over the end of the anvil, but restore the seating at the toe without bending the shoe or putting it out of shape, which you could not do by holding one limb at a time in common tongs, without a great deal of trouble. Plate III. shows you this tool in use with the ground-surface of the shoe 
uppermost for turning up the toe; and you have only to reverse it, keeping the same grasp of the shoe, and the foot-surface will come uppermost, ready to have the seating made good.

I will now suppose that you have shortened the toe of the hoof, rasped away the crust to reccive the turned-up shoe, cut a notch for the clip, and turned up the toe of the shoe: you had better next spring the heels to prevent their burning the back part of the crust while you are fitting the shoe to the fore part; but you must bring them down again before you fit the quarters and heels, and never leave them sprung when the shoe is nailed on.

You must now put the toe of the shoe in the fire, and make it hot enough to mark the uneven portions of horn, which should be rasped away until an even bed is left for the shoe to rest upon. You need not fear to burn the toe of a strong foot; it can do no harm; but a weak foot with a thin crust of course will not bear much burning. Still, the shoe should be made hot enough 
to scorch the horn and show where it fails to fit close.

When the toe is once properly fitted, there will be very little trouble in fitting the quarters and heels. You have only to bring them in over the beak of the anvil until the edge of the shoe ranges with the edge of the hoof back to the farthest point of the heel on each side, and continue the same sweep until it nearly touches the frog. There must be none of the shoe left sticking out beyond the hoof, either behind or at the sides of the heels.

I know that a great many smiths are very fond of what are called "open-heeled shoes," which means shoes with straight heels, wide apart, and projecting beyond the hoof, both behind and at the sides; and the only reason I have ever heard in favor of such shoes is a very bad one,-viz.: that the horse requires more support at the heels than he gets from the hoof. But you may depend upon it that nature has made no mistake about it; and if the horse really wanted more support than he gets from the heels of the hoof, he would have had 
it. But I think I shall prove to you that this kind of shoe, instead of being a benefit to the horse, is a positive evil to him: it interferes with his action, and exposes his sole and frog to serious injury from stones in the road, and the projecting portions of the shoe become ledges for stiff ground to cling to and pull the shoe off. More shoes are lost through these mischievous projections at the heels than from all other causes put together.

Let us see how it is that these projecting heels interfere with the horse's action. It is not necessary for this purpose to trouble you with the anatomy of the foot, but merely to state that all its parts are joined to each other in such a manner as to form one great spring, and that the foot is joined to the leg by the pastern and coronet bones in a direction slanting forward, which brings the foot a little in advance of the leg, and places the heels in front of a line dropped from the centre of the fetlock joint to the ground.

Plate VIII., Fig. 3.-1. The shank or canon bone. 2. The pastern bone. 3. The coronet bone. 4. The 

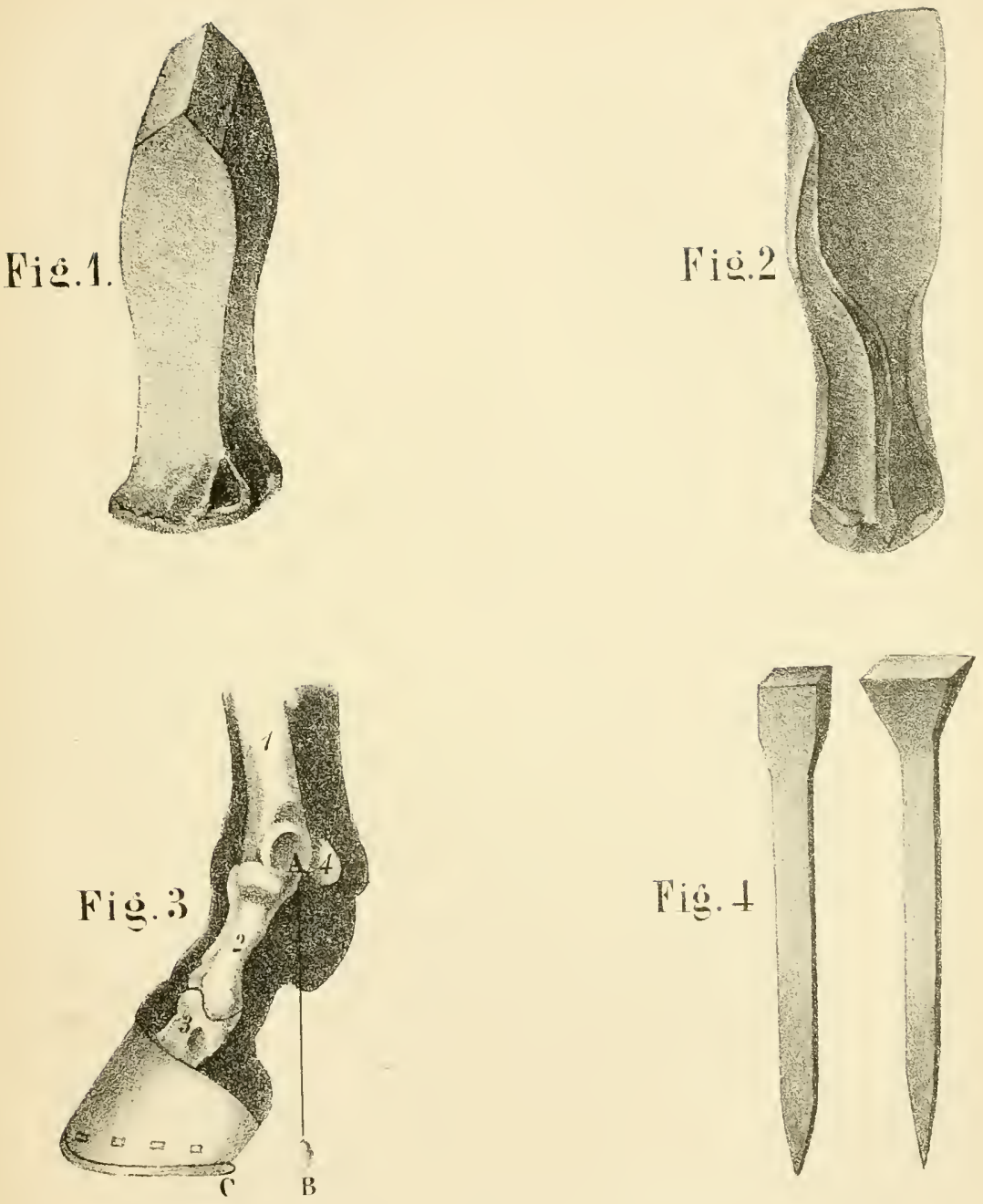

HERLINE \& CO.LITH PHILA 
sessamoid bone. A. The point where the weight of the horse would fall upon the upper end of the pastern bone. B. The point where a line dropped from A would meet the ground. C. The heel of the hoof. Now, it is clear that the weight of the horse will fall upon the upper end of this slanting pastern bone at every step; and the bone, having a joint at each end of it, will sink to the weight thus thrown upon it and break the force of the shock both to the leg and foot; but if the heels of the shoe are longer than the heels of the hoof, the projecting pieces of iron will meet the ground farther back than the natural heels would have done, and will check the sinking of the pastern bone, just as an upright pastern does, by bringing the heels too much under the centre of the weight, which causes the horse to step short and go stumpy.

If you wish to avoid these evils and keep the horse's shoes on his feet, you must bring in the heels, and let the shoe strictly follow the form of the foot, whatever that form may be.

The part of the foot that needs protection from 
injury, more than any other, is the "navicular joint," which rests upon the frog about an inch or an inch and a quarter behind its point; and the only way to protect it is to keep the web of the shoe as wide at the heels as it is at the toe, and to bring in the heels until they nearly touch the frog. By so doing you lessen the opening of the shoe, and the web of one side or the other will strike upon the stones in the road and save the frog from coming with full force upon them. But open-heeled shoes leave the frog entirely exposed to very large stones, and cause many. a bruise to the navicular joint which lays the foundation of future incurable lameness.

I have often seen shoes so wide at the heels that I have placed my clenched hand within the opening of the shoe without touching either side of it; and where my fist could go a stone as large could go. Another great advantage of bringing in the heels and fitting the shoe close, is the certainty that the horse will not cast his shoe: you leave nothing for stiff ground to lay hold of, and, if you slightly berel the inside-quarter and heel of the shoe from 
the foot downwards, no ground in the world can pull it off, for the foot, expanding to the weight of the horse, enlarges the hole made by the shoe and leaves more space for the shoe to come out of than it made for itself to go in at; but if the shoe projects beyond the hoof at any part, and more particularly at the heels, the foot camnot fill the hole made by the shoe, and stiff clay will cling round the projection and pull the shoe off.

Having so far finished the shoe, place it on the face of the anvil with the toe hanging over the side, and see that the foot-surface of the quarters and heels are quite level; then make it hot enough to scorch the hoof all round and form a bed for itself; without this it would be next to impossible to insure close fitting, for, after you have made the foot as level as you can with the rasp and the shoe as level as you can on the anvil, the chances are very much against their fitting like two planed boards, as they ought to do; and the quantity of horn to be thus removed is so small as not to be worth thinking about. It is a mistake to sup- 
pose that a hot shoe injures the hoof: it does nothing of the kind; and you cannot possibly fit a shoe properly without making it hot. I would not have you burn a shoe into its place on the foot before you had taken care to make both the foot and the shoe as level as you could; but when you have done that, the small quantity of burning that is necessary to make them come close together can do no harm. I have said before that a weak, thin crust will not bear as much heat as a strong one, and that the shoe should be applied less hot to it; nevertheless, it must be scorched, that you may be sure the shoe fits properly.

When you have cooled the shoe, you should "back-hole" it,- - that is, make a free opening on the foot-surface for the nails to pass through; but mind that in doing so you do not make the holes incline inwards, by brcaking down the inner edge of the holes more than the outer edge.

Before you "file up" the shoe, hold it firmly in its place on the foot with both hands, and examine carefully whether any light appears between the 

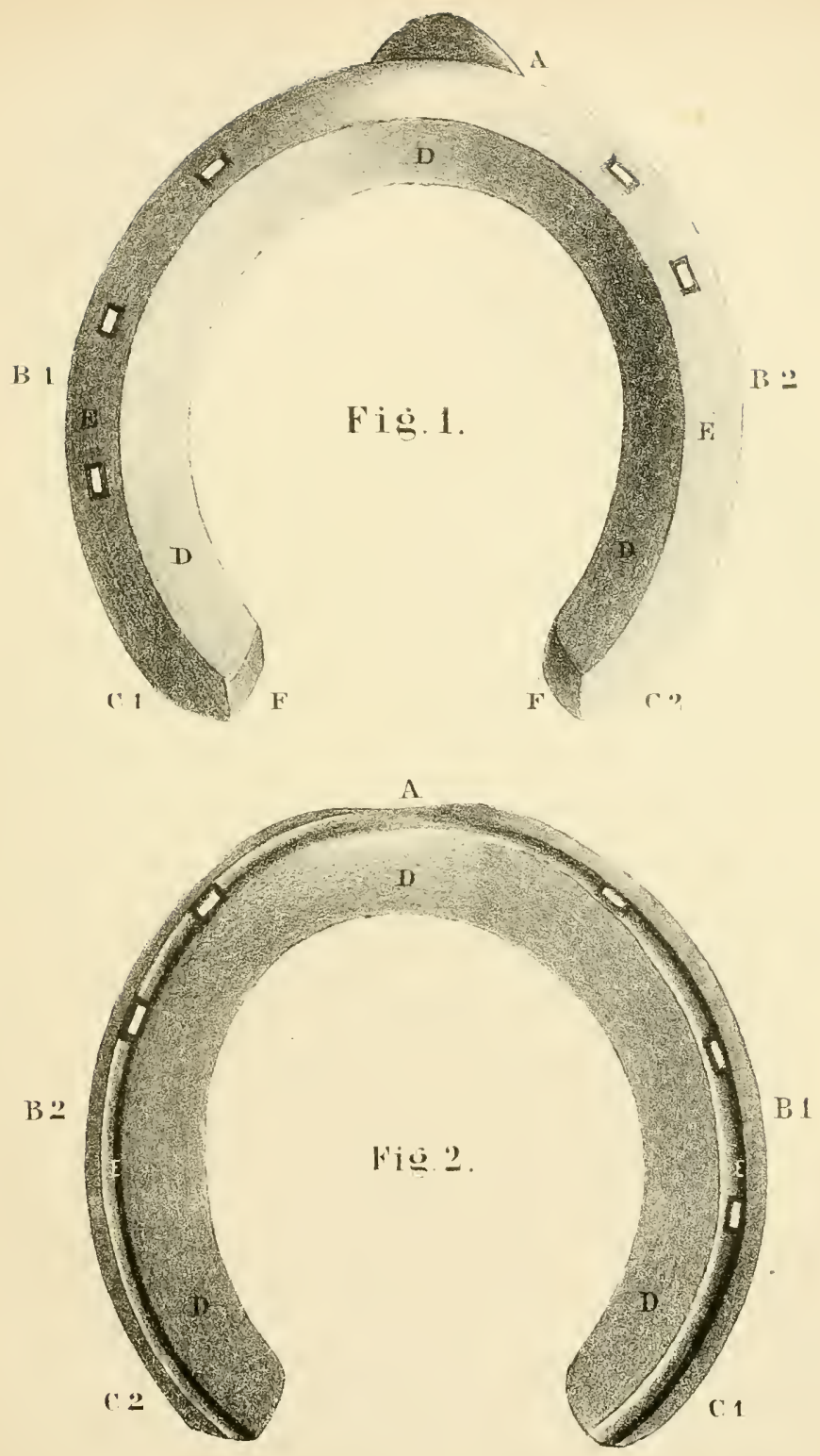

foot and the shoe, and, if you should perceive any, alter the shoe at once; for the crust must bear upon the shoe all round before you can say that the shoe fits the foot as it ought to do.

\section{FILING UP THE SHOE.}

Much time is often wasted in polishing the shoe with the file before it is mailed on; but all that is really needed is to get rid of the burs about the nail-holes, remove the sharp edges of the shoe, and round off the heels; taking care to apply the file hard to that part of both heels which comes next to the frog, so as to slant it from the ground upward and away from the frog; but you must not narrow the ground-surface of the web at the heels in doing so. Plate 4 represents both surfaces of a near fore-shoe; Fig. I shows the foot-surface, and Fig. 2 the ground-surface.

In Fig. 1, A is the clip at the toe, B 1 the outer quarter, B 2 the inner quarter, C 1 the outer heel, C 2 the inner heel, D the seating, E the flat sur- 
face for the crust to bear upon, $\mathrm{F}$ the heels bevelled off away from the frog.

In Fig. 2, $\mathrm{A}$ is the toe, turned up out of the line of wear, B 1 the outer and B 2 the inner quarter, C 1 the outer and C 2 the inner heel, D the ground-surface of the web, as wide at the heels as it is at the toe, $\mathrm{E}$ the fullering, carried all round the shoe.

\section{NAILS.}

I must say a few words about the nails before we come to nailing on the shoe; because the nails in common use are as badly formed as they well can be. Their short wedge-shaped heads, wide at the top and narrow at the bottom, with shanks springing suddenly from the head without any shoulder and ending in a long, narrow point, are most unsafe to trust a shoe to. The head of such a nail can never perfectly fill the hole in the shoe, for the wide top gets tied either in the fullering, or the upper part of the hole, before the lower 
part has reached the bottom, and when the head is about half worn away the lower part is left loose in the hole and the shoe comes off. Now the nails I advise you to use-and you had better always make them for yourself-should have heads which are straight-sided at the upper part and gradually die away into the shank at the lower part, so as to form a shoulder which will block the opening made in "back-holing" the shoe, and keep the shoe firmly in its place until it is quite worn out.

If you compare the two mails I have drawn, you will at once see which promises the firmer hold.

Your nails should be made of the very best nailrods you can get, and they should not be cooled too quickly, but be left spread about to cool by degrees; the longer in reason they are cooling, the tougher they will become. They should not, however, be allowed to lie in a heap to cool; the mass keeps in the heat too long, and makes them almost as brittle as if they had been cooled too suddenly. 


\section{NAILING ON THE SHOE.}

If the nails are of a proper shape, the holes straight through the shoe, and the shoe fits the foot, it requires very little skill to nail it on; only put the point of the nail in the middle of the hole, keep the nail upright and drive it straight: it must come out in the right place, low down in the crust, without the possibility of wounding the sensitive parts of the foot. The shank of the nail will pass straight through the substance of the crust and gain a good firm hold of it, leaving you the strongest part from which to form a clench. The clenches should be short and broad, and not thinned by rasping away any of their substance, but hammered at once into a notch made in the hoof under each, and the rasp should never be allowed to go over them after they have been hammered down; for the sharp steel rasp is very apt to cut through the soft iron elench just where it turns down, and leave the appearance of a clench, when in truth, it has been cut off at the bend 

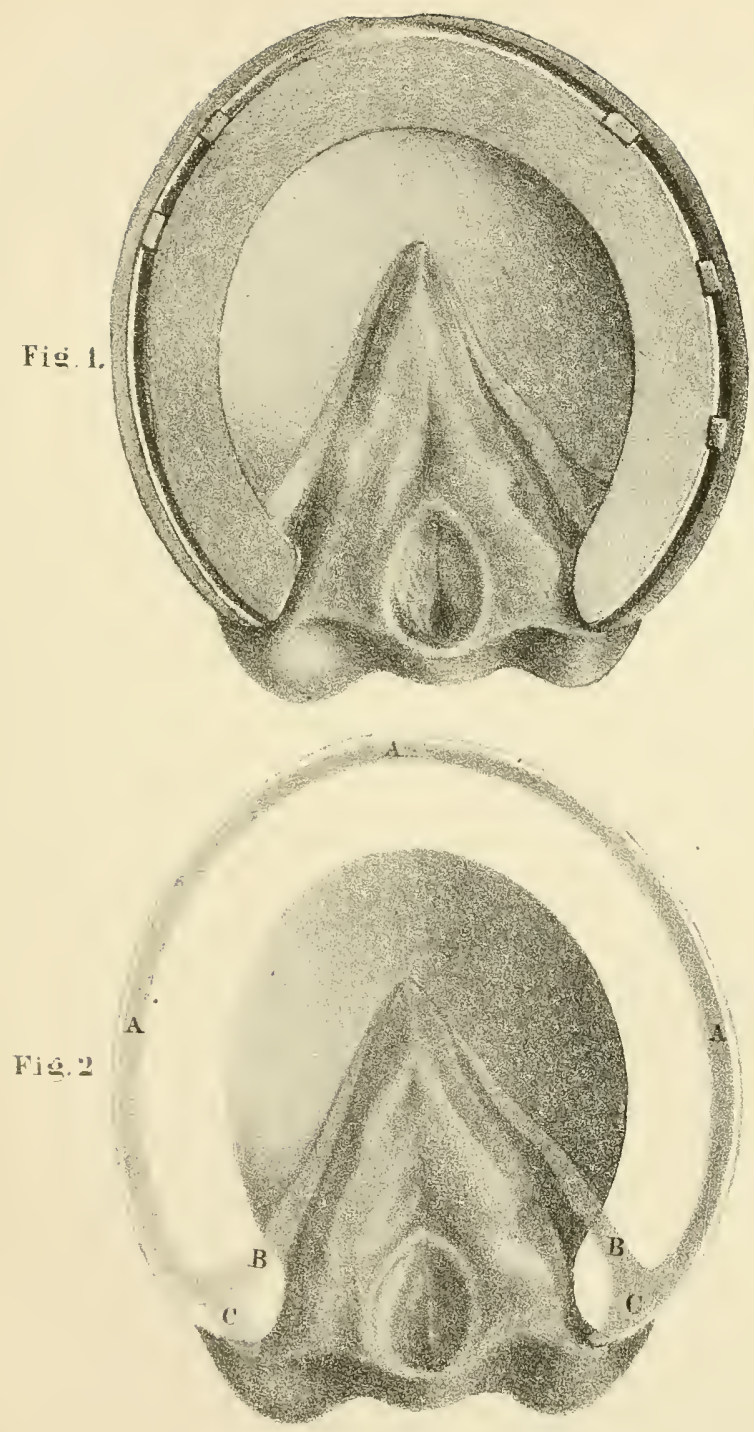

and the loose end only remains buried in the notch in the hoof. You will do good by rasping below the clenches, because you will remove the horn that has been destroyed by the former nails; but on no account ever use the rasp abore the clenches. If you do, you will tear off the thin outer covering of the hoof, which is placed there for the purpose of retaining the natural moisture and keeping the horn tough; and if you rasp it away you will expose the horn to the air, and it will soon become dry and brittle and make the hoof difficult to shoe. This thin covering of the hoof is like the shining covering of a man's finger-nail; and most people know from experience how dry and brittle and easily broken a finger-nail becomes when by any accident it loses that covering.

Plate V. represents the ground-surface of a near fore-foot with the shoe nailed on by five nails. Fig. 1 shows the shoe in its place on the foot, and Fig. 2 represents the same shoe made transparent, so that the parts of the foot that are covered by it are seen through it. A shows the 
crust, $\mathrm{B}$ the bars, and $\mathrm{C}$ the heels of the hoof supported by the shoe. I have invariably found that corns disappear altogether from a horse's foot after it has been shod two or three times in this manner, and that they never return while the same method of shoeing is continued.

\section{SHOEING WITH LEATHER.}

Many tender-footed horses travel best with a covering over the sole, and leather is commonly used for the purpose; but I think gutta percha a quarter of an inch thick, or waterproof felt of the same thickness, answer better, because they both resist wet and do not alter their shape as leather does. When leather is wetted it becomes soft and heavy and yielding; but in drying again it contracts and luardens, causing a frequent change of pressure on the frog, which does not happen with cither of the other two substances. I have used felt for the last three or four years, and prefer it very much. But whichever covering you use, it must be 
put on in the same way; so I will at once tell you how to do it. 'You must fit the shoe to the foot with as much care as if nothing were to be put under it; and when it is "filed up," and ready to be put on, lay it with the foot-surface downward on the covering, whatever it may be, and mark the form of the shoe upon it with the end of the drawing-knife; then cut the piece out, put it in its place upon the shoe, and fix them both in the vice, which will hold them close together, while you carefully cut the edge of the covering until it agrees with the edge of the shoe; then turn them in the vice together, so as to bring the heels of the shoe uppermost, and cut out a piece slightly curved downward from heel to heel, that nothing may be left projecting for the ground to lay hold of. The next thing to do is to smear the whole of the under-surface of the foot well with Barbadoes tar mixed with a little grease; but be sure that you never use gas-tar instead of the other; for it dries up the horn and makes it as hard as flint, while Barbadoes tar keeps it moist and tough. Then you 
must fill the hollow between the frog and the crust on both sides with oakum (which is better for the purpose than tow) dipped in the tar, pressing it well into the hollow until the mass rises above the level of the frog on each side; but never put any oakum upon the frog itself, excepting a piece in the cleft to prevent the dirt and grit working in; very little is ever wanted on the sole in front of the frog. The use of the oakum is to protect the foot, but more especially the navicular joint, which lies above and across the frog, from being jarred by stones on a hard road; and the best way of doing this is to fill the space on each side of the frog with oakum in such a manner that it shall share the pressure with the frog and prevent the full force of the shock from falling on the navicular joint.

The usual mode of stopping a foot is to place a thick wad of tow over the whole surface of sole and frog together, making bad worse, by adding to the projection of the frog and causing it to meet the ground sooner and receive the full force of the jar. 

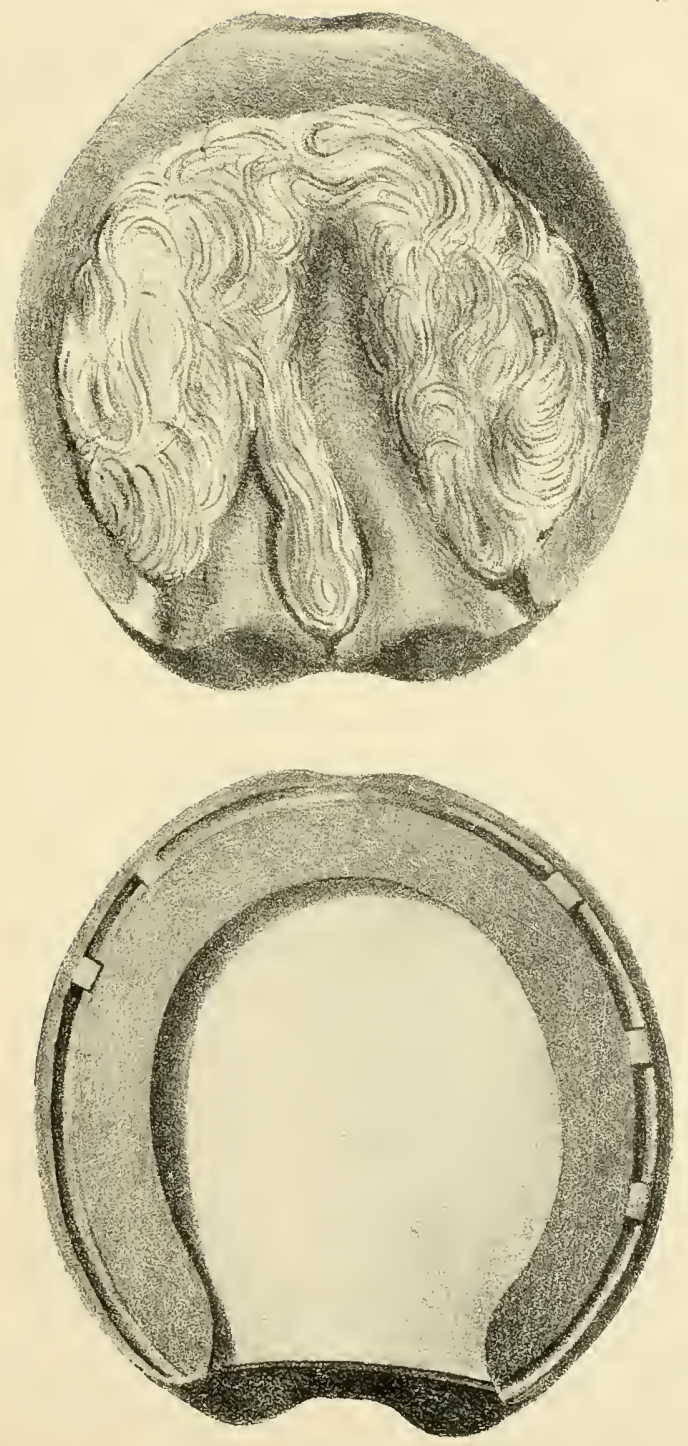

HERLINE \& CO. LITH. PHILA 

You must now nail on the shoe with five nails, exactly as you would do if there was nothing under it; and if you have attended to the fitting there will be no fear of the shoe shifting or coming off.

Plate VI., Fig. 1, shows a foot stopped, ready for shoeing. The ends of the oakum placed in the cleft of the frog are collected together and carried across the body of the frog, to be mixed with the oakum on one side, which keeps it in its place in the cleft and prevents it from working out behind.

Fig. 2 shows a foot properly shod with leather, and also the shape to which the leather should be cut between the heeis of the shoe.

\section{THE HIND-SHOE.}

The hind-shoe, like the fore-shoe, should be brought in at the heels and be made to follow the exact shape of the hoof; but, as the weight of the horse falls differently upon the hind-feet to what it does upon the fore-feet, and as the rider often 
obliges the horse to stop suddenly and without warning when he is least prepared to do so, it becomes necessary to guard against strains of the hock and back-sinews, by raising the heels of the shoe; but this should be done in such a manner as will give both heels an even bearing upon the ground. Calkins may be, and, I believe, are, useful to heavy draught-horses, but they are objectionable for fast work; and turning dlown the outside-heel alone should never be done; it throws the weight upon the inner quarter, which is the least able to bear it, and strains the fetlock joint. The plan I have adopted for many years is to have the last inch and a half toward the heel forged thicker than any other part of the shoe; the heels are then made red-hot, and the shoe is put in the vice with the hot heels projecting, which are beaten down with a hammer until they are about an inch long, and then the sides are made eren and the foot and ground-surfaces level on the anvil. I have found horses travel pleasanter and receive less damage to their hocks, back-sinews, and fetlock 
joints, with these heels to their hind-shoes, than they have with any others that I have tried.

The toe of the hind-shoe is exposed to great wear, and should be made stout and thick, and rather pointed, with a small clip in the middle, to prevent the shoe from being driven backward; and the back-edge of the web should be rounded off, to guard against "overreach." The toe should rest fairly on the ground, to enable the horse to get a good purchase for throwing his weight forward. It is a bad plan to make the toe broad and to place clips at the side of it; it is almost sure to cause the very evil it was intended to prevent, by making the horse "forge," as it is called.

Many persons think that "forging" is caused by the front of the toe of the hind-shoe striking against the heel of the fore-shoe; but that is a mistake. The sound is produced in this way: when the horse raises his fore-foot from the ground and does not instantly throw it forward, but dwells in the action, the hind-foot, following quickly, is forced into the opening of the fore-shoe before 
the fore-foot gets out of the way; and the corners of the broad toe, made still broader by the clips at the sides, are struck against the inner rim of the web of the fore-shoe on each side just behind the quarters, and cause the unpleasant clicking sound. The only way to avoid this disagreeable noise is to make the hind-shoe narrow at the toe and rather pointed, with the clip in the centre; and then the point of the toe, clip and all, will enter the opening of the fore-shoe held up to receive it, and be stopped by the sole or frog before any part of the two shoes can come together, and the noise will cease.

I have said that you should round off the backedge of the web at the toe to prevent an "overreach." It is commonly supposed that this also is done by the front of the toe; whereas, it is always done by the back-edge, which in a well-worn shoe you will find is as sharp as a knife. Now, if the horse in galloping does not lift his fore-foot from the ground and throw it forward in time to make way for the hind-foot, the himd-foot overreaches it, 


\section{Fis 1 .}

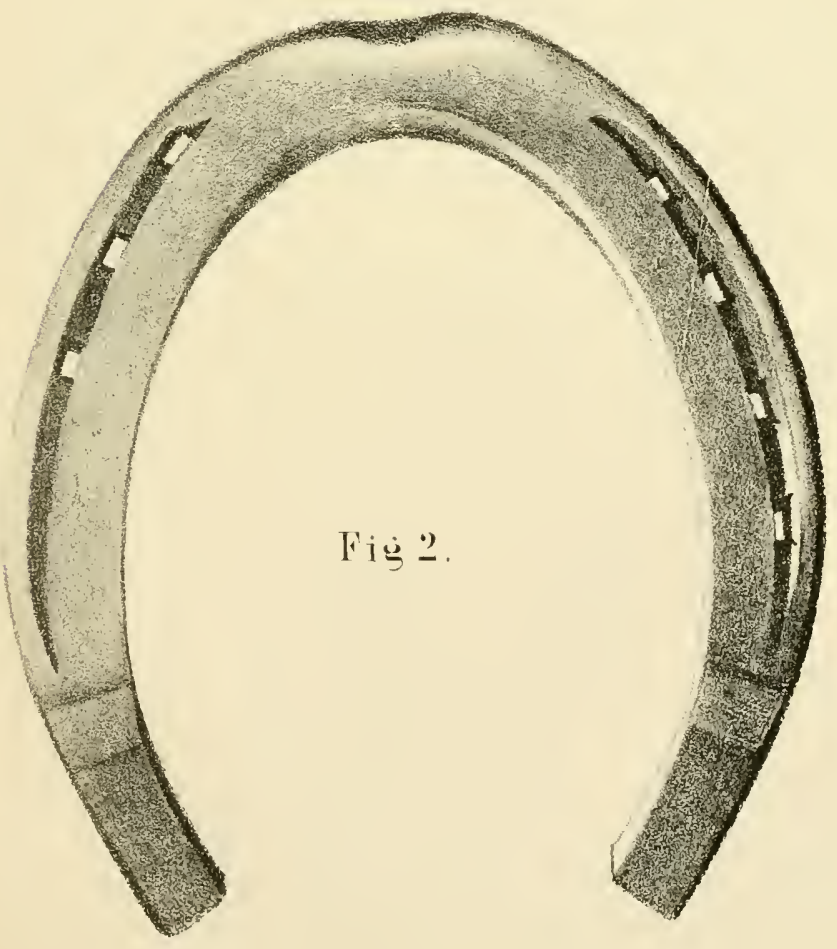




$$
\text { - }
$$


and cuts a piece out of the soft parts above the heel and produces a very troublesome wound.

The hind-foot expands less than the fore-foot; still, you should place the nail-holes so as not to confine the foot. I have found four nails on the outside and three on the inside sufficient to hold any hind-shoe firmly to the foot. The looles on the inside should be stamped closer together than those on the outside, and they should be placed forward toward the toe, so as to leave the inside quarter and heel free to expand. A small foot may be shod with three nails on each side; but no foot requires more than seven altogether.

Plate VII. represents a near lind-shoe. Fig. 1 shows a level surface for the foot to rest upon, the raised heels and the thickened toe, with a small clip in the centre.

Fig. 2 shows the toe rather pointed, the back edge rounded, and the nail-holes properly placed. 


\section{CUTTING.}

Horses strike their feet against the opposite leg in such a variety of ways, both before and behind, that it is impossible to form a shoe that would suit every case of "cutting." I therefore advise you, whether the horse cuts before or behind, to fasten something like a boot covered thickly with wetted pipeclay over the place where he strikes the leg, and then trot him along the road; he will soon pick off some of the pipeclay with the opposite foot, and show you the exact part of the shoe he strikes with, which you can easily alter in the new shoe; and you will often be surprised to see how small a matter causes the mischief.

\section{REMOVING.}

The time at which a horse's shoes should be removed must depend very much upon circumstances. If a horse wears his shoes out in less than a month they had better not be removed; and horses 
with thin, weak horn, which grows slowly, are likewise better left alone between each shoeing, unless their shoes last six or seven weeks, in which case they should be removed once within the time: but horses with strong feet and plenty of horn, that wear their shoes a full month, should have them removed at the end of the first fortnight; and when horses are doing so little work or wear their shoes so lightly that they last two months, they should be removed every fortnight, and at the second removal the shoes should be put in the fire and refitted, or the feet will outgrow the shoes; as the horn grows much quicker when a horse is idle than it does when he is in full work.

Having now gone carefully through all the circumstances necessary to good shoeing, and stated the reasons why certain things should alworys be done, and certain other things never done, I will repeat shortly the few things which are to be clone in the order in which they occur; and you will find that they are really very few when separated from the reasons and explanations. 
Raise the clenches with the buffer.

Have only one foot bare at a time.

Pare out the foot; but leave the frog alone.

Cut off the heels of the shoe as I have directed.

Open the nail-holes straight through the shoe.

Form a clip at the toe, and turn up the toe of the shoe.

Fit the toe, then the quarters, and lastly the heels.

Meat the shoe, and apply it to the foot to see that it fits properly.

Cool the shoe, "back-hole" it, and file it up.

Nail it on with five nails, coming out low in the crust.

Hammer down the clenches without rasping them, and only rasp the hoof below them.

\section{GENERAL OBSERVATIONS.}

I have said that five nails are sufficient to hold on a fore-shoe at any kind of work, in any coun- 
try and at any pace; and I again advise you to employ that number, placing three on the outside of the shoe and two on the inside, because I know from experience that with the very commonest care on the part of the smith they will hold a shoe through any difficulty of ground or pace. But I am prepared to prove that they are more than sufficient for the purpose, and to show that many smiths can and clo keep on a fore-shoe by three nails only-two placed on the outside and one on the inside.

It is very nearly seven years since I have had more than three nails in the fore-shoe of any one of my six horses, and they are all shod with thick felt and stopping; some of them do not require the felt, but, having begun it as an experiment some years ago, and finding no inconvenience from it, I have gone on with it. In a former work I published several cases of horses having done a variety of work with only three nails in each foreshoe; and I may now add another, which happened to a horse of my own last year, and which ought 
to set the question at rest, supposing any doubt still to exist as to the capability of three nails to hold a shoe. The horse I allude to is twentyeight years old; he is a high stepper, and impetuous in company, and has large flat fect, which grow horn very sparingly, so that it is quite necessary to protect his feet by a stont shoe with felt and stopping under it. He happens to be a particularly nice lady's horse for one who has plenty of nerve and can ride well; and I lent him to join in a large riding party of ladies and gentlemen, on a visit at a friend's house, who took long daily rides in a very hilly district, regardless of pace, over commions covered with heath, furze, and stones, through rough stony lanes, and in every variety of ground; and, although his shoes had been on ten days when I sent him away, he returned to me at the end of five weeks with his shoes worn out certainly, but firm on his feet and the clenches all close. I mention this last circumstance because it is a proof that his shoes had been put on with proper care; for whenever 
you find a clench risè you may be certain that you have done something wrong; either the crust did not bear upon the shoe all round, or the nailholes did not pass straight through the shoe, or the heads of the nails did not fill the bottom of the holes. Any one of these things may cause a clench to rise; and a risen clench is a sure sign of careless shoeing.

I may mention, as further proof of the sufficiency of three nails to keep on a shoe, that Colonel Key, who commands the 15th Hussars, at present stationed at Exeter, has four horses shod with three nails only in each fore-shoe. Finding how my horses were shod, he was induced to try the plan upon his hack, and felt so satisfied with the result that he immediately had the others similarly shod, and continues to do so; and an officer in the Prussinn Hussars, who did me the honor to translate my book upon the Horse's Foot into German and publish it at his own expense at Frankfort-sur-Maine, writes me that his horses also are shod with three 
nails only in each fore-shoe, and that he finds no difficulty whatever in keeping their shoes on.

I think I may consider that I have now proved beyond dispute that a fore-shoe can be kept on by three nails; therefore, he must be a sorry bungler indeed who cannot manage it with five.

\section{THE END.}




\section{PUBLICATIONS}

\section{OF \\ HENRY CAREY BAIRD,}

SUCCESSOR TO E. I. CAREY,

No. 7 Hart's Buildings, Sixth Street above Chestnut, Philadelphie.

\section{Stientifit and gigratical.}

\section{American Miller and Millwright's As. sistant:}

A new and thoroughly revised Edition, with additional Engravings. By Wilimam Carter Hughes. In one volume,

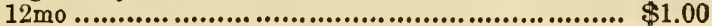

"The author offers it as a substantial reference, instead of speculative theories, which belong only to those not immediately attached to the business. Special notice is also given of most of the essential improvements which have of late been introduced for the benefit of the Miller."-Savannah Republican.

"The whole business of making flour is most thoroughly treated by him."Bulletin.

"A very comprohensive view of the Millwright's business."-Southern Literary Messenger.

\section{Analytical Chemist's Assistant .}

A Manual of Chemical Analysis, both Qualitative and Quantitative, of Natural and Artificial Inorganic Compounds; to which are appended the Rules for Detecting Arsenic in a Case of Poisoning. By Frederick WeHrer, Professor of Chemistry in the University of Göttingen. Translated from the German, with an Introduction, Illustrations, and copious Additions, by Oscar M. Lreber, Author of the "As. sayer's Guide." In One Volume, $12 \mathrm{mo................} \mathrm{\$ 1.25}$

"The character of WarLER is a sufficient guarantee that this work will proto what it claims to be." - Providence Daily Journal. 
Barnard-Connecticut Common School Journal, from 1838 to 1842.

Edited by Henkr Barnard. In one, two, or four vols....\$3.00

Barnard-History of the System of Common Schools, and other Means of Popular Education in Connecticut, from 1638 to $1844.600 \mathrm{pp} \ldots . . \$ 2.00$

Barnard-Journal of Rhode Istand Institute of Instruction,

Including Mr. Barnard's Reports on the History and Improvement of the Public Schools of Rhode Island, from 1845 to 1848. Three volumes...................................... $\$ 3.50$

Barnard-Legal Provision respecting the Education and Employment of Children in Factories and Manufacturing Establishments. 84 pp...50 cts.

\section{Barnard-Life of Thomas H. Gallaudet;}

With a History of Deaf Nute Instruction, \&c., 268 pp.....\$1.00

\section{Barnard-National Eclucation in Europe:}

Being an Account of the Organization, Administration, Instruction, and Statistics of Public Schools, of different grades, in the Principal States. By Henry Barnard, Second edition, 8 vo........................................ $\$ 3.00$

Barnard-Normal Schools; or, Institutions, Agencies, and Means for the Professional Education and Improvement of Teachers, in Europe and the United States. $650 \mathrm{pp}$.........................\$2.00

Barnard-Practical Illustrations of the Principles of School Architccture. $176 \mathrm{pp} . . . . . .75$ cts.

\section{Barnard-School Architecture;}

Or, Contributions to the Improvement of School Houses in the United States. By Henry Barnard, Superintendent Common Schools in Connecticut. 5th edition, 8vo.. $\$ 2.00$ 


\section{Booth and Morfit-The Encyclopedia of Chemistry, Practical and Theoretical:}

Embracing its application to the Arts, Metallurgy, Mineralogy, Geology, Mledicine, and Pharmacy. By Janes C. Booth, Melter and Refiner in the United States Mint; Professor of Applied Chemistry in the Franklin Institute, \&c.; assisted by CAMPBeli Morfit, author of "Chemical Manipulations," \&c. Complete in one volume, royal octavo, 978 pages, with numerous wood cuts and other illustrations....................................................... \$5.00

"It covers the whole field of Chemistry as applied to Arts and Sciences. * * * As no library is complete without a common dictionary, it is also our opiuion that none can be without this Encyclopedia of Chemistry." - Scientific American.

"A work of time and labour, and a treasury of chemical information."-North American.

"By far the best manual of the kind which has been presented to the Amercan public."-Boston Courier.

\section{Brewer; (The Complete Practical)}

Or, Plain, Concise, and Accurate Instructions in the Art of Brewing Beer, Ale, Porter, \&c. \&c., and the Process of Making all the Small Beers. By M. Lafayette Byrn, M.D.

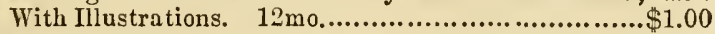

"Many an old brewer will find in this book valuable hints and suggestions worthy of consideration, and the novice can post bimself up in his trade in all its parts."-Artisan.

\section{Builder's Pocket Companion:}

Containing the Elements of Building, Surveying, and Architecture; with Practical Rules and Instructions connected with the subject. By A. C. Smeaton, Civil Engineer, \&c. In oue volume, $12 \mathrm{mo} . \ldots \ldots \ldots \ldots \ldots \ldots \ldots \ldots \ldots \ldots \ldots \ldots \ldots . . . \ldots 1.00$

Contents:-The Builder, Carpenter, Joiner, Mason, Plasterer, Plumber, Painter, Smith, Practical Geometry, Surveyor, Cohesive Strength of Bodies, Architect.

"It gives, in a small space, the most thorongh directions to the builder, from the laying of a brick, or the felling of a tree, up to the most elaborate production of ornamental architecture. It is scientific, without being obscure and unintelligible; and every house-carpenter, master, journeyman, or apprentice, should have a copy at hand always."-Evening Bulletin.

"Complete on the subjects on which it treats. A most useful, practical work." -Balt. American.

"It must be of great practical utility."-Savannah Republican.

"To whatever branch of the art of building the reader may belong, he will find in this something valuable and calculated to assist his progress."- Farmer and Mechanic.

"This is a valuable little volume, designed to assist the student in the acqursition of elementary knowledge, and will be found highly advantageous to every young nan who has devoted himself to the interesting pursuits of which it treats."-Va. Herald. 


\section{Byrne-The Practical Metal-worker's Assistant;}

For Tin-Plate Workers, Braziers, Coppersmiths, Zinc-Plate Ornamenters and Workers, Wire Workers, Whitesmiths, Blacksmiths, Bell Hangers, Jewellers, Silver and Gold Smiths, Electrotypers, and all other Workers in Alloys and Metals. Edited by Oliver Brrne. Complete in one volume, octavo................................................\$4.00

It treats of Casting, Founding, and Forging; of Tongs and other Tools; Degrees of Heat and Management of Fires; Welding; of Heading and Swage Tools; of Punches and Anvils; of Hardening and Tempering; of Malleable Iron Castings, Case IIardening, Wrought and Cast Iron. The management and manipulation of Metals and Alloys, Melting and Mixing. The management of Furnaces, Casting and Founding with Mletallic Moulds, Joining and Working Sheet Metal. Peculiarities of the different Tools employed. Processes depend. ant on the ductility of Metals. Wire Drawing, Drawing Mretal Tubes, Soldering. The use of the Blowpipe, and every other known Metal Worker's Tool.

\section{Byrne-The Practical Model Calculator;}

For the Engineer, Machinist, Manufacturer of Engine Work, Naval Architect, Miner, and Millwright. By Ortver Byrne, Compiler and Editor of the Dictionary of Machines, Mechanics, Engine Work and Engineering, and Author of various Mathematical and Mechanical Works. Illustrated by numerous engravings. Complete in one large volume, octavo, of nearly six hundred pages.....................\$3 $\$ 30$

"In short it must be regarded by every man for whose more especial benefit it is intended, as a complete text-book in his profession."-Pittsburgh Union.

\section{Cabinet-mater's and Upholsterer's Com- panion:}

Comprising the Rudiments and Principles of Cabinet-making and Upholstery, with Familiar Instructions, illustrated by Examples for attaining a proficiency in the Art of Drawing, as applicable to Cabinet Work; the processes of Veneering, Inlaying, and Buhl Work; the Art of Dyeing and Staining Wood, Bone, Tortoise Shell, \&c. Directions for Lackering, Japanning, and Varnishing; to make French Polish; to prepare the best Glues, Cements, and Compositions, and a number of Receipts particularly useful for Workmen generally. By J. Stokrs. In one volume, 12mo. With Illustrations...............................75 cts.

"A large amount of practical information, of great service to all concerned in thase branches of business."-Ohio State Journal. 


\section{Chemistry Applied to Dyeing.}

By James Napier, F.C.S. Illustrated. 12mo

Contents.-General Properties of Matter.-Ieat, Light, Elements of Matter. Chemical Affiuity. Nom-Netullic Substances.-Oxygen, Hydrogen, Nitrogen, Chlorine, Sulphur, Selenium. Phosphorus, Iodine, Bromine, Fluorine, Silicum, Boron, Carbou. Metallic Substances.-General Properties of Metals, Potassium, Sodium, Lithium, Soap, Barium, Strontium, Calcium, Magnesium, Alminum, Manganese, Iron, Cobalt, Nickel, Zinc, Cadmium, Copper, Lead, Bismuth, Tin, Titanium, Chromium, Vanadium, Tungstenum or Wolfram, Molybdenum, Tellarium, Arsenic, Antimony, Uranium, Cerium, Mercury, Silver, Gold. Platinum, Palladium, Iridium, Osmium, Rhodium, Lanthanium. Mordants.-Red Spirits, Barwood Spirits, Plumb Spirits, Yellow Spirits, Nitrate of Iron, Acetate of Alumina, Black Iron Liquor, Iron and Tin for RoyalBlues, Acetate of Copper. Vegetable Matters used in Dyeing.-Galls, Sumach, Catechu, Indigo, Logwood, Brazilwoods, Sandal-wood, Barwood, Camwood, Fustic, Young Fustic, Bark or Quercitron, Flavine, Weld or Wold, Turmeric, Persian Berries, Saftlower, Madder, Munjeet, Annotta, Alkanet Root, Archil. Proposed New Vegetable Dyes.Sooranjee, Carajuru, Wongshy, Aloes, Pittacal, Barbary Root. Animal Diatters used in Dyeing. - Cochineal, Lake or Lac, Kerms.

This will be found one of the most valuable books on the subject of dyeing, ever published in this country.

\section{Colburn-The Locomotive Engine:}

Including a Description of its Structure, Rules for Estimating its Capabilities, and Practical Observations on its Construction and Management. By Zerah CoLbUnN. Illus-

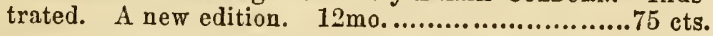

"It is the most practical and generally useful work on the Steam Engine that we have seen."-Eoston Trazeller.

\section{Distiller. (The Complete Practical)}

By M. Lafayette BrRn, M.D. With Illustrations. 12mo.\$1.00

"So simplified, that it is adapted not only to the use of extensive Distillers, but for every farmer, or others who may want to engage in Distilling." -Banner of the Union.

\section{Dyer and Colour-maker's Companion:}

Containing upwards of two hundred Receipts for making $\mathrm{Co}_{0}$ lours, on the most approved principles, for all the various styles and fabrics now in existence; with the Scouring Process, and plain Directions for Preparing, Washing-off, and Finishing the Goods. Second edition. In one volume, $12 \mathrm{mo}$ $75 \mathrm{cts}$.

"This is another of that most excellent class of practical books, which the publisher is giving to the public. Indeed, we believe there is not, for manufacturers, a more valuable work, having been prepared for and expressly adapted to their business."-Farmer and Mechanic.

"It is a valuable book."-Otsego Republican.

"We have shown it to some practical men, who all pronounced it the com. pletest thing of the kind they had seen." $-N$. Y. Nalion. 


\section{Dyer's Instructor:}

Comprising Practical Instructions in the Art of Dyeing Silk, Cotton, Wool, and Worsted and Woollen Goods, as single and two-coloured Damasks, Moreens, Camlets, Lastings, Shot Cobourgs, Silk Striped Orleans, Plain Orleans from White and Coloured Warps, Merinoes, Woollens, Yarns, \&c. \&c. Containing nearly Eight Hundred Receipts, to which is added a Treatise on the Art of Padding, and the Printing of Silk, Warps, Skeins, and Handkerchiefs, and the various Mordants and Colours for the different Styles of such work. By David Smith, Patteru Dyer. 12mo, cloth.

"Information can be obtained from this book which would be found difficult to gain in any other form."-Southern Argus.

\section{Dyer (The Practical) and Scourer.}

By Thosras Lore. In one volume, 12mo. (In press.)

\section{Examination of Dmigs, Medicines, Che- micals, \&c.}

As to their Purity and Adulterations, by C. H. Peirce, M.D., Translator of "Stockhardt's Chemistry," and Examiner of Medicines, \&o. for the Port of Boston. 12mo.....\$1.25

\section{Gilbart-Practical Treatise on Banting.}

By Jas. Wm. Grlbart, F.R.S. Edited by J. Surth Homans,

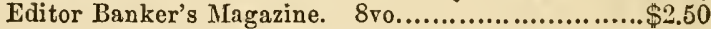

\section{Gregory-Mathematics for Practical Men:}

Being a Common-Place Book of Principles, Theorems, Rules, and Tables, in various Departments of Pure and Mixed Mathematics, with their Applications, especially to the pursuits of Surveyors, Architects, Mechanics, and Civil Engineers, with numerous Engravings. By OLintuus GREGORY, LL.D., F.R.A.S...............................\$1.50

\section{Household Surgery; or, Hints on Emer-} gencies.

By J. F. Soutir, one of the Surgeons of St. Thomas's Hospital. In one volume, $12 \mathrm{mo}$, sheep. Illustrated by nearly fifty Engravings. 
Johnston-Botanic Practice of Medicine.

By Dr. Wr. Johnston. $24 \mathrm{mo}$. $.38 \mathrm{cts}$.

\section{Leslie's (Miss) Complete Cookery:}

Directions for Cookery in its Various Branches. By Miss LesLIE. 54th 'Thousand. Thoroughly Revised, with the Addition of New Receipts. In one volume, 12mo, half-bound, or in sheep.............................................\$1.00

In preparing a new and carefully revised edition of this my first work on cookery, I have introduced improvements, corrected errors, and added new receipts, that I trust will on trial be found satisfactory. The success of the bock (proved by its immense aud increasing circulation) affords conclusive eridence that it has obtained the approbation of a large number of my country. women, many of whom hare informed me that it has made practical housewives of young ladies who have entered into married life with no other acquirements than a few showy accomplishments. Gentlemen, also, have told me of great improvements in the family table, after presenting their wives with this manual of domestic cookery, and that, after a morning deroted to the fatigues of husdness, they no longer find themsel ves subjucted to the annoyance of an ill-dressed dinner.-Preface.

\section{Leslie's (Miss) Two Hundred Receipts in French Cookery.}

A new edition, in cloth.................................25 cts.

\section{Lieber-Assayer's Guide;}

Or, Practical Directions to Assayers, Miners, and Smelters, for the Tests and Assays, by Heat and by Wet Processes, of the Ores of all the principal Metals, and of Gold and Silver Coins and Alloys. By OSCAR M. LIEBER, la te Geologist to the State of Mississippi. 12mo. With Illustrations. $75 \mathrm{cts}$.

"Among the indispensable works for this purpose, is this little guide." Artisan.

Lyon-New and Improved Tables:

With the Method of their Application to finding the Mean Heights of Cross Sections, and the Cubic Contents of Excavations and Embankments. By Parrick Lyon. 8vo..\$1.50

\section{Macfarlane-Propellers and Steam Navi- gation:}

With Biographical Sketches of Early Inventors. By Roвert Macrarlane, C.E., Editor of the "Scientific American." In one volume, $12 \mathrm{mo}$. Illustrated by over eighty Wood Engravings..............................................75 cts. 


\section{Morfit-Perfumery; Its Manufacture and Use.}

With Instructions in every branch of the Art, and Receipts for all the Fashionable Preparations; the whole forming a valuable aid to the Perfumer, Druggist, and Soap Manufacturer. Illustrated by numerous Wood-cuts. From the French of Celnart, and other late authorities. With Additions and Improvements by CaMpBell Morfir. A new and revised edition, in one volume, $12 \mathrm{mo}$, cloth........\$1.50

\section{Morfit-The Arts of Tanning and Cur- rying:}

Theoretically and Practically Considered in all their Details, being a full and comprehensive Treatise on the Manufacture of the various kinds of Leather. Illustrated by over two hundred Engravings. Edited from the French of De Fontenelle and Malapeyere. With numerous Emendations and Additions, by Campbell Morfit, Practical and Analytical Chemist. Complete in one rolume, octaro.....\$5.00

This important Treatise will be found to cover the whole field in the most masterly manner, and it is believed that in no other branch of applied science could more signal service be rendered to American Manufacturers.

The pullisher is not aware that in any other work heretofore issued in this country, more space has been devoted to this subject than a single chapter; and in offering this volume to so large and intelligent a class as American Tanners and Leather Dressers, he feels confident of their substantial support and encouragement.

Conrenrs.-Introduction, Dignity of Labour, Tan and Tannin, Gallic Acid, Extractice Tanning Materials, Oak Barks, Barking of Trees, Method of Estimating the Tanning Power of Astringent Substances, Tan, the Structure and Composition of Skin, Different kinds of Skin suitable for Tanning, Preliminary Treatment of Skins, Tanning Process, Improved Processes, Vauquelin's Process, Accelerating Processes, Keasley's, Trumbull's, llibbards, and Leprieur's Processes, Tanning with Extract of Oak-Bark, Ilemlock Tanning, with Myrtle PIant, English Harness Leather, Calf Skins, Goat and Sheep Skins, Horse IHides, Buck, Wolf, and Dog Skins, Buffalo, or "Grecian" Leather, Rnssia Leather, Red Skins, Wallachia Leather, Mineral Tanning, Texture and Quality of Leather, and the Heans of Discovering its Defeets, Tawing, IIungary Leather, Oiled Leather, Tanning as practised by the Mougol Tartars, Shagreen, Parchment, Leather Bottles, Tanning of Cordage and Sail Cloth, Glazed or "Patent" Lear ther, Helverson's Process for Rendering Hides Ilard and Transparent, Currying, Currying of Calf Skins, Currying of Goat Skins, Red Leather, Fair Leather, Water Proof Dressing, Perkins' Machine for Pommelling and Graining Leather, Splitting, Shaving, Fleshiug and Cleansing Machines, Embossing of Leather, Gut Dressing.

\section{Mortimer-Pyrotechnist's Companion;}

Or, A Familiar System of Fire-works. By G. W. Montner. Illustrated by numerous Engravings. $12 \mathrm{mo} . \ldots \ldots \ldots . . .75 \mathrm{cts}$. 


\section{Poeis and Poetry of the Ancients.}

By Wiluiam Peter, A.M. Comprising Translations and Specimens of the Poets of Greece and Rome. With Engravings.

Cloth extra ...................\$3.00|Turk. moroc. sup. extra.\$5.50

Cloth extra, gilt edge........3.50 Turk. moroc. ant. extra...5.50

Half ealf, antique.

.4 .50 Calf antique, extra

\section{Willis's (N. P.) Poetical Works:}

In one volume, 8vo., with Illustrations by Leutze, and a Portrait.

Cloth, extra, gilt edges...\$5.00| Turk. moroc. sup. extra. $\$ 7.00$

Half calf, antique...........6.00 Turk. moroc. ant. extra...7.00 Calf antique, extra........................\$7.00

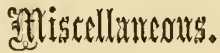

Atalantis, a Poem.

By Widitam Gilmore Simms. 12mo........................50 cts.

Beckford-Vathek, an Arabian Tale.

By Wr. Beckrond. 12mo, eloth................................75 cts. Cloth extra, gilt edges.............................................1.25

\section{Bolingbroke's (Lord) Works.}

Complete in four volumes, $8 \mathrm{vo}$. cloth extra....................\$10.00

Brougham (Lord) - Lives of Men of Letters and Science.

Two volumes, 12mo, cloth.......................................\$2.00

Byron's Life, Letters, and Journals.

By Moore. Complete in two volumes, half morocco....... $\$ 3.00$

Children in the Wood.

Illustrated, $12 \mathrm{mo}$, cloth, gilt edge...............................50 cts. 
Comic Blackstone.

By Gilbert Aввот A'Becket. One rolume, $12 \mathrm{mo}$, cloth..75 cts. Corinne, or Italy.

By MIADANe De STAEe, 12mo, cloth............................\$1.25

Cloth extra, gilt edges.......................................\$1.75

"A work of singular ingenuity and eloquence, and the best guile, or rather compavion, which the traveller can take with him." -J. C. Eustuce.

Cranch's Poenus.

One volume, boards...................................................37 cts.

Feltman-Journal of the Siege of Yorlitown, \&c.

Octavo, boards..........................................................75 cts.

Floral Offering; a Token of Friendship,

Edited by Frances S. OsGood. Illustrated with ten elegantly coloured Groups of Flowers, 4to, extra gilt edges......\$3.50

Gems of the British Poets,

By S. C. HaLL. 12mo, cloth...................................... \$1.00

Imitation morocco.

George St. George Jutian, the Prince.

By the author of "Valentine Vox." Illustrated. 8ro, cloth.\$1.25 Halsted's Life of Richard III.

In one volume, $8 \mathrm{vo}$, cloth.

Hazlitt-Life of Napoleon.

By William HazLitr. Illustrated by 17 Engravings, 8vo, cloth,

gilt ............................................................... \$2.50

Half calf............................................................ \$4.00

Hazlitt-The Miscellancous Works of William Hazlitt.

The five volumes complete in two, $12 \mathrm{mo}$, cloth................\$2.50

Half calf............................................................\$4.00

Ha:litt-Table-Talk.

$12 \mathrm{mo}$, cloth.........................................................\$1.25

Hazlitt-Lectures on the Dramatic Litera-

ture of the Age of Elizabeth, and Characters of

Shakspeare's Plays.

()ne volume, $12 \mathrm{mo}$, cloth 75 cts. 
Hazlitt-Lectures on the English Comic Writers, and on the English Poets.

One volume, $12 \mathrm{mo}$, cloth.....................................75 cts.

Harlitt-Spirit of the Age.

One volume, $12 \mathrm{mo}$, cloth...........................................75 cts.

Heads of the People, or Portraits of the English.

Illustrated. $8 \mathrm{vo}$, cloth

Holm's Account of New Sweden.

One volume, 8 ro, boards

Howitt-Book of the Seasons.

$A$ new and revised edition, $12 \mathrm{mo}$, cloth. (In press.)

Howitt-Student Life in Germany.

A new and revised edition, two volumes, 12mo. (In press.)

Howitt's Travels in Germany, \&c. \&c.

Ouc volume, 8vo. Sheep..............................................\$1.50

Howitt's Visits to Remarkable Places.

Two volumes, 8 vo, cloth, gilt.......................................\$4.00

Kohl's Travels in Austria, Scotland, England and Wales.

One volume. Sheep...............................................\$1.50

Laing's Notes of a Traveller.

One volume, 8vo, cloth. $\$ 2.00$

Landor-Imaginary Conversations of Celebrated Authors.

By Walter Savage Landor. 12mo, cloth. (In press.)...\$1.00

Lanman's Tour to the River Saguenay.

$16 \mathrm{mo}$, cloth ............................................................75 cts.

Life of Major-General Peter Muhlenberg, of the Army of the Revolution.

By Hon. Henrty A. Muhlenberg. 12mo, cloth. 


\section{Lion-Killer (The) of Algeria.}

By Jules Gerard, Lieutenant of Spahis, Army of France. In one volume, 12mo. Illustrated. (In press.)

"In his own particular department he can only be compared to the Changarniers, the Cavaignacs, the Lamoricières, the St. Arnauds-the elite of the African army in theirs. Still in the prime of life, he is in military rank only a lieutenant of Spahis, but as le tueur de Lions, his reputation has spread all over Europe and $A$ frica; the Arabs go in quest of him from the most remote duars, or encampments, in order to enlist his services against their most formidable enemy. Travellers and romancers have vied with one another in giving currency to his exploits. We are not quite sure if the inimitable Dumas does not boast of haring shared a cotelette de lion with the African chasseur."-Colburn's New Monthly.

Memoirs of the Historical Society of Pennsylvania, 1850.

Octavo, boards....

Memoirs of Generals, Commodores, and other Commanders who have received Medals from Congress.

82 Engravings, 8vo, cloth.\$2.50| Half morocco...............\$3.00 Michelet-The Women of the French Revolution.

Translated from the French of J. Mrchelet, by a Lady of Philadelphia. In one volume, $12 \mathrm{mo}$. (Just ready.)...... $\$ 1.00$ Modern Chivalmy, or Adventures of Captain Farrago and Teague O'Regan.

One volume, $12 \mathrm{mo}$, with Illustrations by DarLer. Sheep... $\$ 1.00$

North's Specimens of the British Critics.

By Professor Wrison. One volume, $12 \mathrm{mo}$, cloth............\$1.00

Our Army at Monterey.

By T. B. Thorpe. lllustrated. 1 vol. $16 \mathrm{mo}$, cloth gilt...62 cts.

Our Army on the Rio Grande.

By T. B. ThonPe. With 26 Illustrations. 1 vol. $16 \mathrm{mo}$, cloth. 62 cts.

Robinson Crusoe.

Complete. Illustrated. 1 vol. $16 \mathrm{mo}$, cloth, gilt side.....75 cts. Cloth, gilt edges.........................................\$1.00

Roscoe's Lorenzo de Medici.

Two volumes, 8 vo, cloth, gilt, reduced to $\$ 3.00$ 
Ryley, the Itinerant; or, Memoirs of an Actor.

Two volumes, $12 \mathrm{mo}$. (In press.)

Sanderson's American in Paris.

Two volumes, $12 \mathrm{mo}$, cloth. $\$ 1.75$

Scott's Miscellanies.

Three volumes, cloth gilt.\$3.50 | Half morocco, or calf.....\$4.25

Senter's Journal of Arnold's Expedition to Quebec, in 1775.

Octavo, boards. .62 cts.

Sermon on the Mount.

Illuminated, boards......\$1.50 | Illuminated, silk.

Illuminated, morocco, antique $\$ 4.00$

Simms, (W. G.)-Helen Halsey.

$12 \mathrm{mo}$, cloth. (Nearly ready.)

Simms, (W.G.)—Castle Dismal.

12mo, cloth. (Nearly ready.)

Sullivan's (William) Public Characters of the American Revolution.

Octavo, with a Portrait, cloth. $\$ 2.75$

Smith's (Sidney) Miscellanies.

Three volumes, 12mo, cloth. Fine edition.

Half morocco, or calf............................................... $\$ 3.75$

Smith's (Sidney) Sermons.

12mo, cloth

Stephen's Miscellanies.

One volume $12 \mathrm{mo}$, cloth gilt

Half morocco, or calf..

$\$ 1.25$

Thierry's Historical Essays and Narratives of the Merovingian Era.

One volume, 8vo, cloth..................................................\$1.50

Townsend's Narrative of the Battle of

Brandywine, with illustrative Documenis.

Octavo, boards. $\$ 100$ 


\section{Three Hours, or the Vigil of Love.}

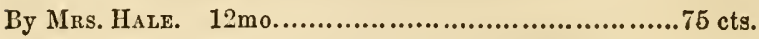

\section{Wood-Personal Recollections of the Stage,}

Embracing notices of Actors, Authors, and Auditors, during a period of Forty Years. By William B. Wood, Late Director of the Philadelphia, Baltimore, Washington, and Alexandria Theatres. Third Thousand. In one volume, 12 mo. With a Portrait................................ $\$ 1.25$

"Take it altogether, its historical accuracy, perfect familiarity with all that concerns the stage, with its decided literary merit, and we may safely pronounce this the great hook of this theatrical age, the best work that has ever appeared on this subject, and one that all will read and be delighted with."-American Curier.

"We have read otber theatrical histories and biographies, Cibbers and Bellar my's, in England, and Dunlap's and others, here; but none of them have a genial, gentle spirit like this."-North American.

"Any narrative of bis life would be sure to find numerous readers. They will not be disappointed in auy expectations they may have formed of its nierit as a dramatic history or literary work."-Evening Bulletin.

"The author is now in his serenty-sixth year. In closing his long professional career by the preparation of this rolume, be bas performed an acceptable public service, and made a valuable addition to the dramatic bistory of the country." $-N$. I. Journal.

"We sincerely congratulate the lovers of the legitimate old-fashioned drama, on the rich treat that awaits them in the volume now before us, for which we owe our thanks to the enterprising publisher. There is no man better qualified than Mr. Wood, to give interest and zest to such a work.

"We are certain that the most fastidious critic will find as much to admire in the style of his narrative, as in the raciness of bis anecdote, and the wisdom of his reflections." - National Intelligencer.

"A most valuable and interesting work."-Saturday Post.

"A most copious and interesting historical record of his times."-Daily News.

"The debut of Cooper, the peculiar talents of Jefferson or Matthews, the success of Cooke, and Kean, and Booth; the sensation produced by the Kembles, Power, Forrest, and Fanny Elsler-the book before us tells us something of them all."-City Item.

"It is exceedingly interesting."-Sunday Dispatch.

"We without besitation pronounce it the most interesting, entertaining, and instructive book of the kind that has ever come ander our notice."-Sunday Press.

"Ife revives, in his lively and graceful sketches, reminiscences which must please every frequenter of the drama in its best days, and brings vividly back to mind persons and things grateful to the memory, though time bas almost obliterated them."-Ledger.

"Destined, from its piquancy and inexbaustible fund of information, to attain a world-wide reputation." - Argus.

"The work is an epitome of an actor's life-a life indeed, for it identifies the author with the drama for fifty years."-Pennsylvanian.

\section{Willis's (N. P.) Prose Works.}

In one volume, royal $8 \mathrm{vo}, 800$ pages, cloth gilt............\$3.00 Cloth extra, gilt edges...\$3.50| Half calf antique............4.50 Library sheep.................3.50 Turk. moroc. sup. extra...6.00 
Walpole-The Castle of Otranto.

A Gothic Story. By Horace W Walpole, Earl of Orford. With a Memoir of the Author, by Lond Dover. In one volume,

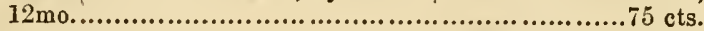

It has been thought that a handsome and readable edition of Walpole's remarkable romance would be welcomed by the American public, and the publisher therefore offers the present, which he feels satisfied will, like Beckford's "Vathek," meet with a ready and large demand.

"The actors in the romance are strikingly drawn, with bold outlines, becom. ing the age and nature of the story. Feudal tyranny was perhaps never better exemplified than in the character of Manfred. IIe has the courage, the art, the duplicity, the ambition of a barbarous chieftian of the Dark Ages, yet touches of remorse and natural feeling, which preserve some sympathy for him when his pride is quelled and his race extinguished.

"The story is happily detailed, its progress is uniform, its events interesting and well-combined, and the conclusion grand, tragical, and affecting." - Sir Wulter Scott.

"The first romance in our language."-Lord Byron.

"One of the most remarkable of his works."-Lord Dover.

"What I will venture to call a masterpiece. * * * *

Where a beautiful imagination, supported by strength of judgment, has enabled the author to go beyond his subject, and effect the full purpose of an ancient tragedy."-Dr. Wurburton.

"A series of supernatural appearances put together under the most interesting form imaginahle."-Baron de Grimm.

"The brilliant success of the new romance soon made the author declare himself.-IVarburton's Memoirs of Wulpole.

Wyatt's History of the Kings of France. Illustrated by Seventy-two Portraits, 1 vol. $16 \mathrm{mo}$, cloth... $\$ 1.50$

\section{Crerenge gurbliantions.}

Bowl of Punch.

With Seventy plates, paper. $50 \mathrm{cts}$.

Brougham's Lives of Men of Letters and Science.

New Series. 12mo, paper $.50 \mathrm{cts}$.

Fisher's Photogenic Manipulation.

Two parts.................................................................50 ets. Ghost Stories.

With Ten Engravings, by DarLEY.................................50 cts Kohl's Travels in Austria......................25 cts. Kohl's Travels in England and Wales..25 cts. 
Kohl's Travels in Scotland. .25 cts.

Lanman's Tour to the River Saguenay.

Paper................................................................50 cts.

Mexico, Before and After the Conquest.25 cts. Modern Chivalry.

With 10 Illustrations, by DARLEY, in 2 vols. paper.........75 ets.

My Shooting Box.

by Franis Forrester. Paper.....................................50 cts.

Our Army at Monterey.

By T. B. Thовpе

$.50 \mathrm{cts}$.

Our Army on the Rio Grande.

Twenty-six Illustrations, by T. B. THORPE.....................50 cts.

Pickings from the Port-fotio of the Reporter of the New Orleans Picayune.

Paper, Eight plates......................................................50 ets.

Punch's Comic Blackstone.

Complete. Paper

.50 cts.

Punch's Labours of Hercules.

Complete. Paper. 25 cts.

Punch's Natural History of Courtship.

Paper..................................................................25 cts.

Punch's Peep into London Society. Paper.......................................................................25 cts.

Punch's Medical Student.

Second Series. Paper.................................................25 cts.

Thierry's Historical Essays.

One volume, 8vo. Paper.

$\$ 1.25$

Torloch O'Brien..............................................12 cts.

Illustrated................................................................37 cts.

Tupper's Author's Mind. $37 \mathrm{cts}$. 


$$
\text { - }
$$


. 




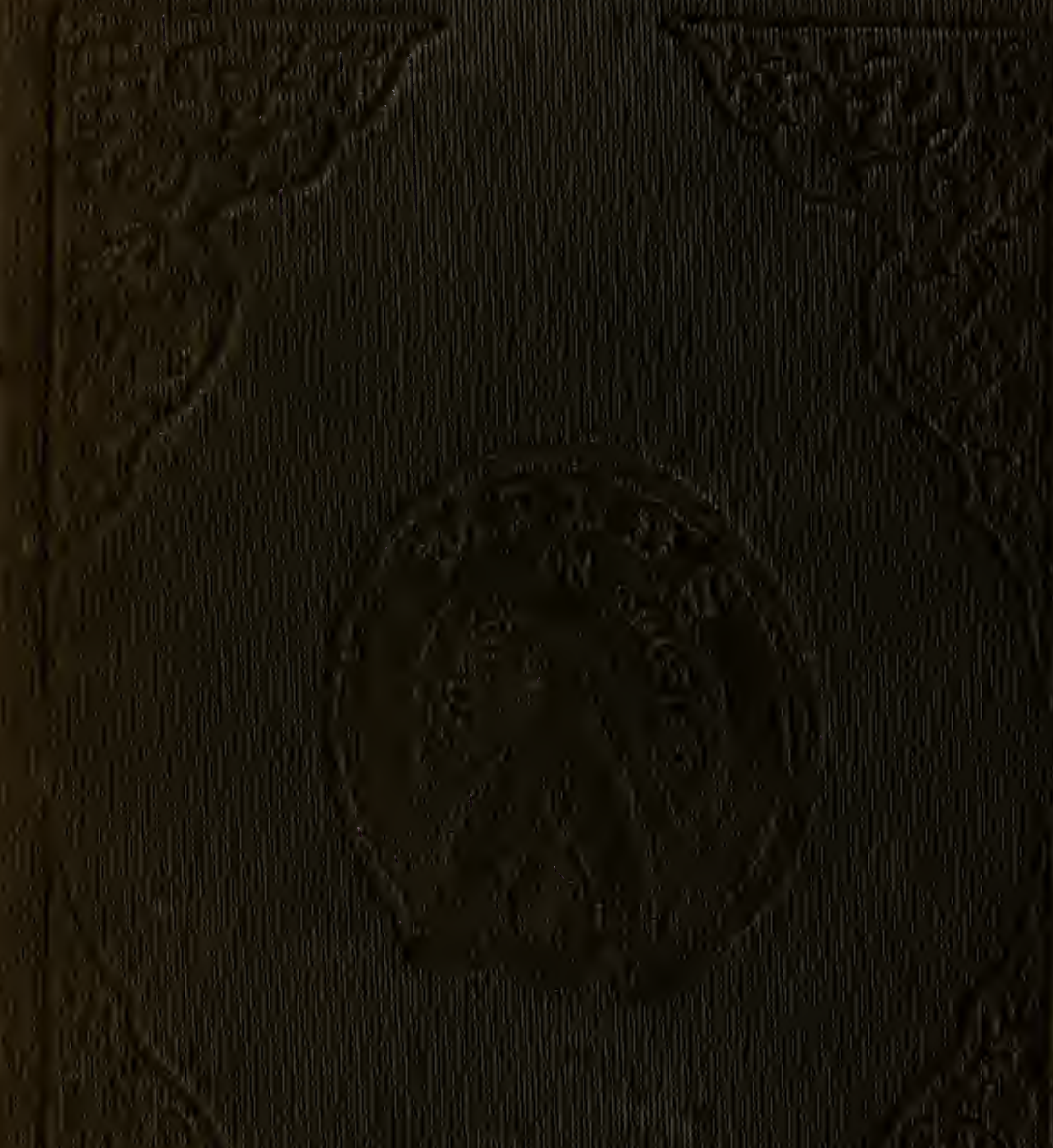

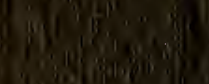

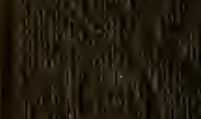

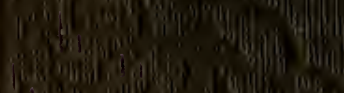

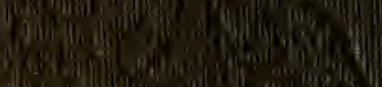
A. 